\title{
Termination of obligate anoestrus and induction of fertile ovarian cycles in dogs by administration of purified pig $\mathrm{LH}$
}

\author{
J. Verstegen ${ }^{1}$, K. Onclin ${ }^{1}$, L. Silva ${ }^{1}$ and P. Concannon ${ }^{2}$ \\ ${ }^{1}$ Department of Small Animal Reproduction, University of Liege, Liege 4000, Belgium; and \\ ${ }^{2}$ Department of Physiology, College of Veterinary Medicine, Cornell University, Ithaca, NY, USA
}

\begin{abstract}
The potential role of $\mathrm{LH}$ in the initiation of the follicular phase in dogs was investigated by treating anoestrous bitches with highly purified pig $\mathrm{LH}(n=16)$ or saline $(n=8)$ three times a day for 7 days, beginning in either early anoestrus (days 94-116 of the cycle) or midanoestrus (days 124-145). Treatment with LH induced pro-oestrus within 7 days $(n=16)$, and oestrus $(n=12)$ and fertile ovulations $(n=7)$ at $16+3$ days, while pro-oestrus in bitches treated with saline did not occur until 46-166 days after the start of treatment. Six of the seven ovulating bitches whelped normal litters. The bitches in which pro-oestrus but not oestrus occurred were all treated in early anoestrus. During treatment, plasma oestradiol in bitches treated with $\mathrm{LH}$ increased from $8+2 \mathrm{pg} \mathrm{ml}^{-1}$ to $20+5 \mathrm{pg} \mathrm{ml}^{-1}$ within 1 day, and reached higher peak values $\left(45+7 \mathrm{pg} \mathrm{ml}^{-1}\right)(P<0.05)$ than those observed in saline-treated controls $\left(9+3 \mathrm{ng} \mathrm{ml}^{-1}\right)$. These results demonstrate that $\mathrm{LH}$ treatment alone can terminate anoestrus by inducing a normal follicular phase in dogs. The results also suggest that, in normal cyclic bitches, anoestrus is the result of insufficient LH secretion, and that spontaneous pro-oestrus could be the result of increased LH secretion in the presence of already adequate concentrations of FSH.
\end{abstract}

\section{Introduction}

Dogs are a monoestrous species and experience oestrous cycles with spontaneous ovulations at intervals that range typically from 5 to 12 months (mean, 7 months). After pregnancy, which lasts about 2 months, or the non-pregnant luteal phase, which lasts 2-3 months, there is an obligate anoestrus which lasts 2-10 months (mean, 5 months). During anoestrus, circulating concentrations of immunoreactive FSH are relatively high and those of LH are low in relation to mean concentrations observed throughout the cycle (Olson et al., 1982; Concannon, 1993). LH concentrations during anoestrus are low owing presumably to infrequent pulsatile secretion. At the end of normal anoestrus, concentrations of LH are increased in samples collected once a day (Olson et al., 1982), in association with an increased frequency of pulsatile secretion (Concannon, 1993). The endocrine factors responsible for spontaneous termination of anoestrus in dogs are not well understood. An increase in sensitivity to $\mathrm{GnRH}$ in late anoestrus (Haaften et al., 1992), pre-pro-oestrous increases in oestradiol (Jeffcoate, 1993) and a decline in prolactin (Onclin et al., 1995) could each play a role. Fertile oestrus has been induced prematurely in anoestrous dogs by pulsatile i.v. administration of $\mathrm{GnRH}$ every 90 min (Vanderlip et al., 1987; Cain et al., 1989; Concannon et al., 1997), injection of a $\mathrm{GnRH}$ agonist three times a day (Cain et al., 1990), or constant subcutaneous infusion of a GnRH-agonist for several days (Concannon, 1993; Concannon et al., 1993). However, because GnRH administration would be

Received 6 January 1997 expected to increase concentrations of FSH as well as LH, these studies provided no information about the relative importance of $\mathrm{LH}$ and FSH in the change in gonadotrophic activity required for either the spontaneous or GnRH-induced reinitiation of pro-oestrus-like follicular activity in bitches. Considering the apparent surfeit of circulating immunoreactive FSH during anoestrus, it is possible that anoestrus in dogs is essentially the result of reduced LH secretion, and that the termination of anoestrus is primarily dependent on increased availability of $\mathrm{LH}$. The present study was conducted to determine whether the administration of $\mathrm{LH}$ alone could induce normal pro-oestrous follicle growth in anoestrous bitches, and to monitor the progress of any LH-induced ovarian cycles by assessing vaginal cytology, fertility and serum concentrations of oestradiol and progesterone.

\section{Materials and Methods}

Animals, treatments and observations

Beagles $2-5$ years old were maintained in breeding colonies under previously described standardized conditions at the University of Liege (Onclin et al., 1993) or Cornell University (Concannon et al, 1987, 1993), and provided with food in amounts to maintain adequate nutrition, and water ad libitum. Females were studied at known days of the ovarian cycle based on determination or estimation of the day of the preovulatory LH surge (Onclin et al., 1993; Concannon, 1993). Anoestrous bitches received serial injections of $\mathrm{LH}\left(0.1 \mathrm{iu} \mathrm{kg}^{-1}\right)$ or saline 
$\left(0.15 \mathrm{~mol} \mathrm{NaCl}{ }^{-1}\right)$ i.m. in volumes of $1.0-1.8 \mathrm{ml}$. The $\mathrm{LH}$ was a highly purified preparation of pig LH (pLH-B-69-007; J.F. Beckers, University of Liege) which had negligible contamination with other hormone activity. The pig $\mathrm{LH}$ was prepared as described by Closset et al. (1975) for human LH, using ion exchange DEAE and Sephadex gel filtration chromatography as described by Nowshari et al. (1995). The purification of LH was monitored by assay of fractions using a specific radioimmunoassay (Ectors et al., 1974) and radioreceptor assay (Catt et al., 1972). The LH bioactivity of the final preparation was determined by LH radioreceptor assay using bovine luteal cell membranes, and in comparison with competitive binding achieved with NIH-LH-B9 (1 iu $\mathrm{mg}^{-1}$ ). The FSH bioactivity of the pLH was determined by FSH radioreceptor assay (Beckers ef al., 1977) using pig testis membranes, and in comparison with a pig FSH with a potency of $40-60 \mathrm{iu} \mathrm{mg}^{-1}$ (Nowshari ef al, 1995). The $\mathrm{LH}$ content was $0.32 \mathrm{iu} \mathrm{mg}^{-1}$; the FSH content was $0.002 \mathrm{iu} \mathrm{mg}^{-1}$. The resulting ratio of LH:FSH was 160:1 (J. F. Beckers, personal communication).

The bitches included 12 in early anoestrus at days 94-116 $(103 \pm 3)$ of the cycle which received either LH $(n=8)$ or saline $(n=4)$, and 12 in mid-anoestrus at days $124-145$ (137 \pm 8$)$ of the cycle which also received either $\mathrm{LH}(n=8)$ or saline $(n=4)$. $\mathrm{LH}\left(0.1 \mathrm{iu} \mathrm{kg}^{-1}\right)$ or saline was administered three times a day, at 6-10 h intervals, for 7 days. At the onset of behavioural oestrus or at the time vaginal smears contained $\geq 80 \%$ superficial epithelial cells, bitches were paired with a male at intervals of 1-3 days and mated on separate days a total of between two and seven times.

\section{Animal observations}

All animals were observed each day for external signs of pro-oestrus including serosanguinous discharge. Vaginal smears were obtained every $1-2$ days throughout treatment, throughout any observed pro-oestrus and oestrus, and until the end of vaginal cornification. Vaginal smears were examined for changes in number of epithelial cells, and the percentage of epithelial cells that were cornified (Concannon and DiGregorio,
1986). The first day of pro-oestrus was considered to be the first day there was serosanguinous discharge, vulval swelling, and $\geq 20 \%$ intermediate or cornified epithelial cells in the vaginal smear. Bitches that did not cycle and ovulate within 50 days of the start of treatment were monitored for signs of the next pro-oestrus. The inter-pro-oestrus interval was calculated as the time from the onset of the previous prooestrus until the first pro-oestrus after initiation of treatment. The day that progesterone in samples collected each day in late pro-oestrus and early oestrus increased above $1 \mathrm{ng} \mathrm{ml} \mathrm{ml}^{-1}$ was recorded as day 0 of the cycle (Concannon et al., 1977; Onclin et al., 1993). The day of ovulation was considered to be 2 days after the initial increase in plasma progesterone above $1 \mathrm{ng} \mathrm{ml}^{-1}$.

\section{Blood samples and hormone assays}

Plasma was harvested from blood samples obtained every I-2 days from 1 day before treatment until 16 days after treatment, and then between one and three times a week until day 50. Blood was collected by jugular venepuncture into heparinized evacuated tubes, centrifuged at $1500 \mathrm{~g}$ for $20 \mathrm{~min}$, and plasma aliquots were frozen until assayed. Progesterone concentrations were measured by radioimmunoassay using a commercial radioimmunoassay kit (DPC Progesterone-Coat-aCount, Diagnostic Products Inc., Humbeek) as previously validated for dog plasma (Srikandakumar et al., 1986). The sensitivity of the progesterone assay at $95 \%$ binding was $0.1 \mathrm{ng} \mathrm{ml}^{-1}$, with inter- and intra-assay coefficients of variation of $5 \%$ and $9 \%$, respectively.

Concentrations of oestradiol were determined using commercial assay reagents (DPC Double Antibody Estradiol Radioimmunoassay, Diagnostic Products Inc.). Validation was based on evaluation for parallelism and recovery of added oestradiol. Serial dilutions of oestradiol dissolved in human calibrator serum, phosphate buffer and oestradiol-free canine plasma and serum were assayed along with serial dilutions of normal canine plasma. All curves were parallel $(P>0.82)$ but the oestradiol dilution curves in canine plasma and serum were

Table 1. Mean \pm SEM response intervals and reproductive parameters in beagle bitches administered purified porcine LH during early or mid-anoestrus

\begin{tabular}{|c|c|c|c|c|}
\hline & \multicolumn{2}{|c|}{ LH-treated } & \multicolumn{2}{|c|}{ Saline controls } \\
\hline & Early anoestrus & Mid-anoestrus & Early anoestrus & Mid-anoestrus \\
\hline Bitches & $n=8$ & $n=8$ & $n=4$ & $n=4$ \\
\hline Day of cycle at treatment & $98 \pm 5$ & $134 \pm 10$ & $108 \pm 5$ & $141 \pm 11$ \\
\hline Days to pro-oestrus & $4.3 \pm 0.6^{\mathrm{a}}$ & $3.8 \pm 0.5^{\mathrm{a}}$ & $98 \pm 6$ & $63 \pm 10$ \\
\hline \multicolumn{5}{|l|}{ Incidence $(\%)$} \\
\hline Oestrus and ovulation & $38 \%$ & $50 \%$ & $100 \%$ & $100 \%$ \\
\hline Split oestrus & $13 \%$ & $50 \%$ & NA & NA \\
\hline No oestrus & $50 \%$ & $0 \%{ }^{b}$ & NA & $\mathrm{NA}$ \\
\hline Days to ovulation & $72 \pm 20^{a}$ & $23 \pm 7^{\mathrm{a}, \mathrm{b}}$ & $108 \pm 6$ & $73 \pm 10$ \\
\hline (range) & $(13-165)$ & $(15-36)$ & $(100-130)$ & $(53-102)$ \\
\hline
\end{tabular}

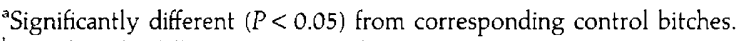

bSignificantly different $(P<0.05)$ from early-anoestrous LH-treated bitches. 


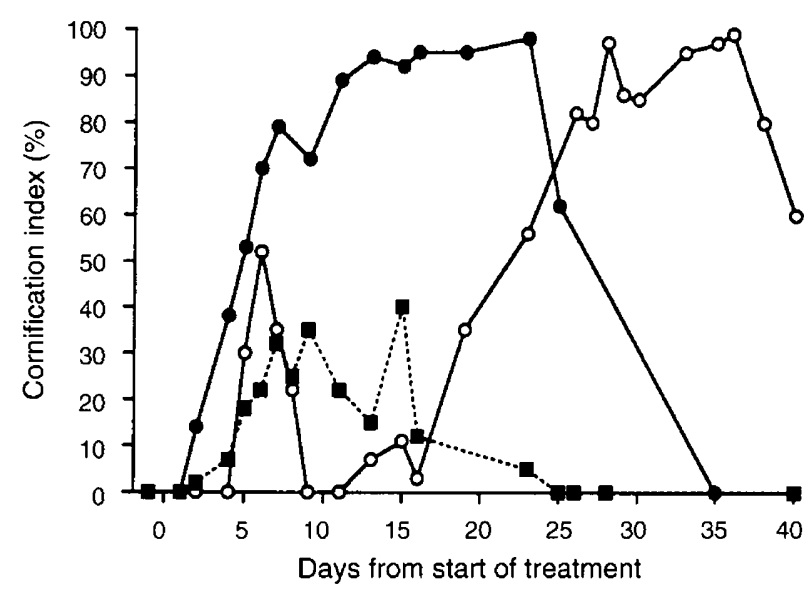

Fig. 1. Mean percentages of superficial-type epithelial cells in vaginal smears obtained from anoestrous bitches that responded to injections of purified pig LH with: a weak or no response $(\boldsymbol{\square}, n=4)$, pro-oestrus without ovulation (that is, split heat; $O, n=5$ ), or oestrus and ovulation (that is, a normal response;,$n=7$ ).

displaced from that of the human calibrator standard. Therefore, samples were assayed as recommended by the manufacturer but using oestradiol standard curves prepared by dilution of oestradiol in oestradiol-free canine plasma. In addition, in each assay, oestradiol-free aliquots of each sample were also assayed as sample blanks to correct for any sample-specific plasma effect. Oestradiol-free plasma was prepared by mixing $1 \mathrm{ml}$ plasma with $1 \mathrm{ml}$ Dextran-T70 coated charcoal solution ( $1 \mathrm{~g}$ Norit A charcoal, $0.25 \mathrm{~g}$ Dextran-T70, $70 \mathrm{ml}$ of $0.05 \mathrm{~mol}$ PBS $\left.1^{-1}, \mathrm{pH} 7.6\right)$. After incubation for $20 \mathrm{~min}$ at $4^{\circ} \mathrm{C}$ and centrifugation at $3000 \mathrm{~g}$ for $20 \mathrm{~min}$ at $4^{\circ} \mathrm{C}$, the supernatant was collected and used for assay. Assay steps included incubation of $200 \mu \mathrm{l}$ sample with $100 \mu \mathrm{l}$ antiserum for $2 \mathrm{~h}$ at room temperature, addition of $100 \mu \mathrm{l}\left[{ }^{125} \mathrm{I}\right]$-oestradiol conjugate and incubation for $1 \mathrm{~h}$, addition of $1 \mathrm{ml}$ precipitation solution and, after $10 \mathrm{~min}$, centrifugation at $3000 \mathrm{~g}$ followed by decantation of supernatant, and counting of precipitate in a gamma spectrometer. The sample blank, if different from the standard blank value (range of difference $1-19 \mathrm{pg}$ ), was subtracted from the sample value as extrapolated from the standard curve. The addition of $20 \mathrm{pg}$ and $50 \mathrm{pg}$ of oestradiol to each of three plasma samples $\left(4,22\right.$, and $\left.45 \mathrm{pg} \mathrm{ml}^{-1}\right)$ resulted in a recovery of $18 \pm 3$ and $46 \pm 4 \mathrm{pg} \mathrm{ml}^{-1}$, respectively, after assay. The sensitivity of the oestradiol assay at $95 \%$ binding was $2 \mathrm{pg}$ $\mathrm{ml}^{-1}$, with inter- and intra-assay coefficients of variation of $8 \%$ and $12 \%$, respectively.

\section{Statistical analysis}

All values are means \pm SEM. There were no differences owing to location and results for both locations were combined. Differences between or among groups were determined by Student's $f$ test or by one-way analysis of variance and tests of least significant differences (Snedecor and Cochran, 1980).

\section{Results}

In control anoestrous bitches, the intervals from the start of study in early or mid-anoestrus until the onset of pro-oestrus

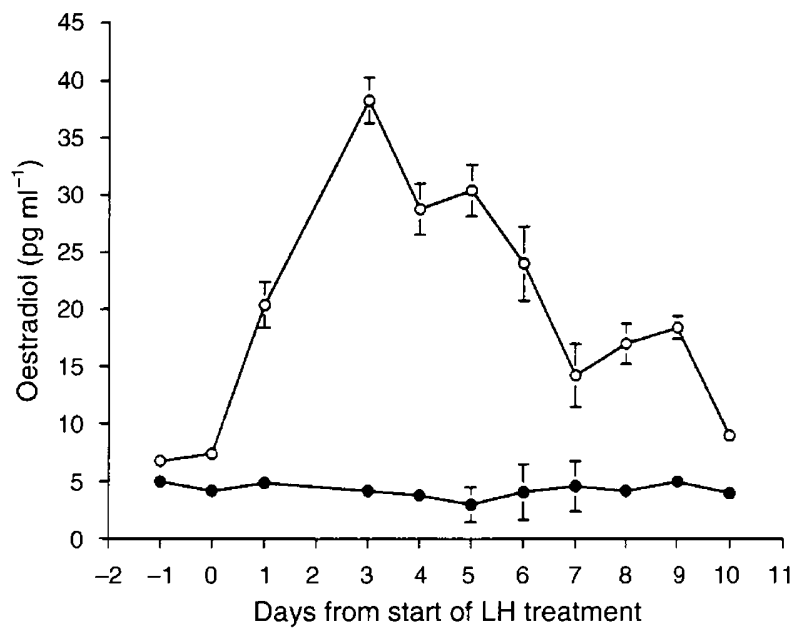

Fig. 2. Mean ( \pm SEM) concentrations of oestradiol in plasma of anoestrous beagle bitches administered saline $(\boldsymbol{0}, n=16)$ or 0.1 iu pig $\mathrm{LH} \mathrm{kg}{ }^{-1}$ every $8 \mathrm{~h}$ for 7 days $(0, n=8)$.

ranged from 42 to 116 days (mean, $89 \pm 12$ days), with resulting inter-pro-oestrous intervals of 191-227 days (mean, $209 \pm 5$ days). LH treatment reduced $(P<0.05)$ both the interval to pro-oestrus and the inter-pro-oestrous interval of bitches treated in either early or mid-anoestrus, compared with bitches in the respective control groups (Table 1). In each bitch treated with $\mathrm{LH}$, signs of pro-oestrus, including serosanguinous discharge and increased number of epithelial cells in vaginal smears were first observed before the end of the 7 days of treatment. The timing did not differ between early and mid-anoestrous bitches. The interval from start of treatment to pro-oestrus ranged from 2 to 7 days (mean, $4.2 \pm 1$.1 days). The resulting inter-pro-oestrous intervals were $107 \pm 3$ days in the eight bitches treated in early anoestrus, and $141 \pm 7$ days in the eight bitches treated in mid-anoestrus, in both instances less $(P<0.05)$ than those of controls.

The pro-oestrus induced in the 16 bitches treated with $\mathrm{LH}$ resulted in normal oestrus and fertile ovulation $(n=7)$; a pro-oestrus or oestrus without ovulation, followed within 10-20 days by another pro-oestrus, oestrus and ovulation $(n=5)$; or a transient or weak pro-oestrus without oestrus or ovulation $(n=4)$. In all treated bitches that had a normal pro-oestrus and oestrus, changes in the vaginal cytology included increases in the percentage of epithelial cells that were superficial to $\geq 90 \%$ and patterns similar to those observed in normal cycles. In bitches that had a pro-oestrus or oestrus without ovulation followed rapidly by normal cycles (that is, a split heat), the peak percentage for superficial cells in smears during the initial response ranged from $40 \%$ to $100 \%$. In bitches with a limited or weak pro-oestrus-only response, the peak for superficial cells during the first 3 weeks of study ranged from $5 \%$ to $40 \%$ (Fig. I).

The mean interval from start of treatment to ovulation in bitches treated with LH was earlier than in control bitches in both early and mid-anoestrus (Table 1). The interval to ovulation in the seven bitches that ovulated during the LH-induced oestrus ranged from 13 to 24 days (mean, $16 \pm 3$ days). The corresponding interval to day 0 of the induced cycle ranged from 11 to 22 days (mean, $14 \pm 3$ days). Matings at the 
(a)

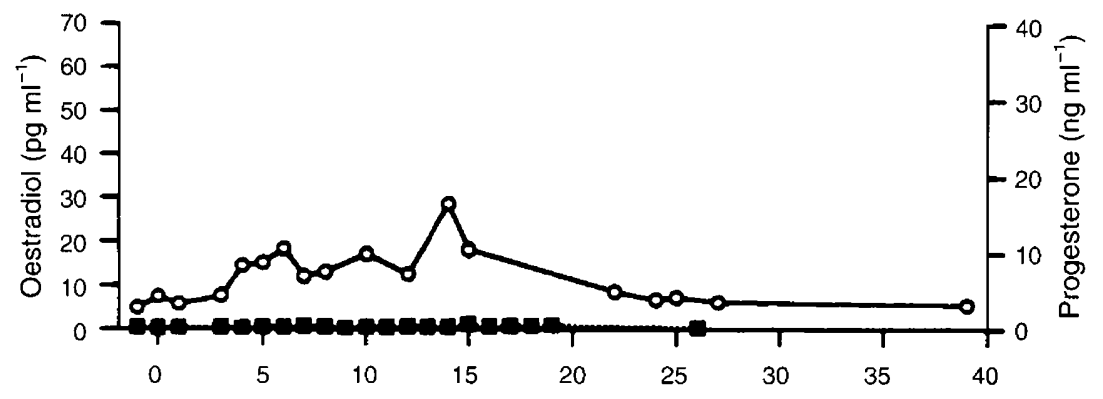

(b)

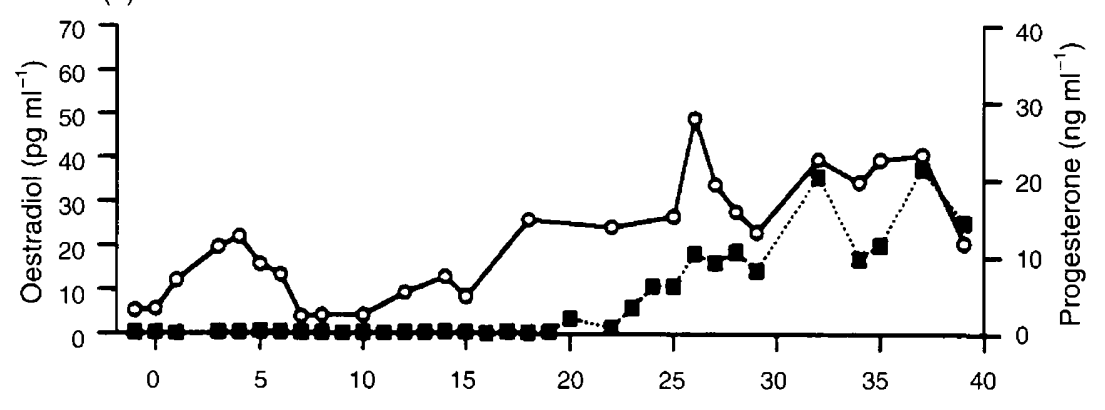

(c)

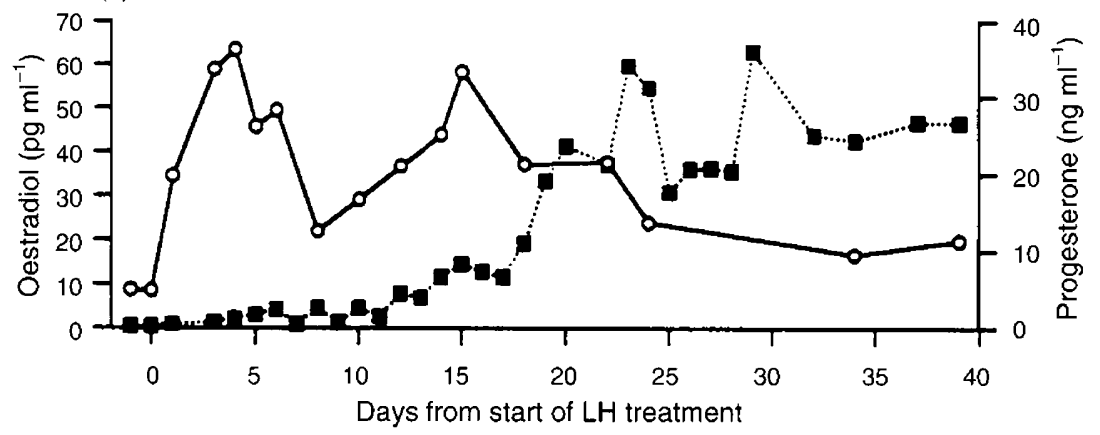

Fig. 3. Mean concentrations of oestradiol $(O)$ and progesterone $(\mathbf{\square})$ in groups of anoestrous beagle bitches that responded to administration of 0.1 iu pig $\mathrm{LH} \mathrm{kg}^{-1}$ every $8 \mathrm{~h}$ for 7 days with (a) transient or weak pro-oestrus only $(n=4$ ); (b) pro-oestrus or oestrus without ovulation $(n=5)$; or (c) normal pro-oestrus, oestrus and ovulation $(n=7)$.

time of the induced oestrus resulted in pregnancy and normal litters in six of the seven bitches. All eight control bitches mated and became pregnant. Parturitions occurred 64-67 days (mean, $65 \pm 1$ days) after the estimated day of the ovulatory LH surge $(n=14)$. Litter sizes were similar in treated bitches (range, 3-7 pups; mean, 3.8 \pm 1.1 pups) and control bitches (range, 3-7 pups; mean, $4.2 \pm 1.6$ pups). In each of the five bitches treated with $\mathrm{LH}$ in which an induced pro-oestrus without ovulation was rapidly followed by a normal prooestrus and oestrus, plasma progesterone concentrations revealed that ovulation occurred during the second oestrus.

There were no differences between bitches treated with $\mathrm{LH}$ in early versus mid-anoestrus in the interval to induced pro-oestrus, or in the incidence of rapidly induced ovulation (Table 1). Therefore, the results of both groups were combined for evaluation of hormone profiles and differences among bitches in response to treatment. However, four of the eight bitches treated in early anoestrus had pro-oestrus-only or weak pro-oestrus responses, whereas none of the eight bitches treated later, in mid-anoestrus, had such limited responses, suggesting an effect of stage of cycle when treated (Table 1).

Before treatment, plasma oestradiol was low in all bitches, ranging from 2 to $12 \mathrm{pg} \mathrm{ml}^{-1}$ (mean, $7.8 \pm 1.6 \mathrm{pg} \mathrm{ml}^{-1}$ ). Oestradiol increased during the period of treatment in bitches treated with LH but not in control bitches (Fig. 2). Mean oestradiol increased $(P<0.05)$ to $20.3 \pm 4.9 \mathrm{pg} \mathrm{m}^{-1}$ after 1 day of treatment. Peak oestradiol concentration during treatment was greater in bitches treated with LH (45 \pm $\left.7 \mathrm{pg} \mathrm{ml}^{-1}\right)$ than in control bitches $\left(9 \pm 3 \mathrm{pg} \mathrm{ml}^{-1}\right)$. On the day after the last $\mathrm{LH}$ injection (day 7 ), oestradiol was higher $(P<0.05)$ in treated bitches $\left(24.0 \pm 4.1 \mathrm{pg} \mathrm{ml}{ }^{-1}\right)$ than in control bitches $\left(3.3 \pm 1.4 \mathrm{pg} \mathrm{ml}^{-1}\right)$. The magnitude of the initial increase in oestradiol was greater in bitches responding with a normal pro-oestrus and oestrus than in bitches responding with pro-oestrus and oestrus without ovulation, or with weak pro-oestrus and incomplete cornification (Fig. 3). In those 


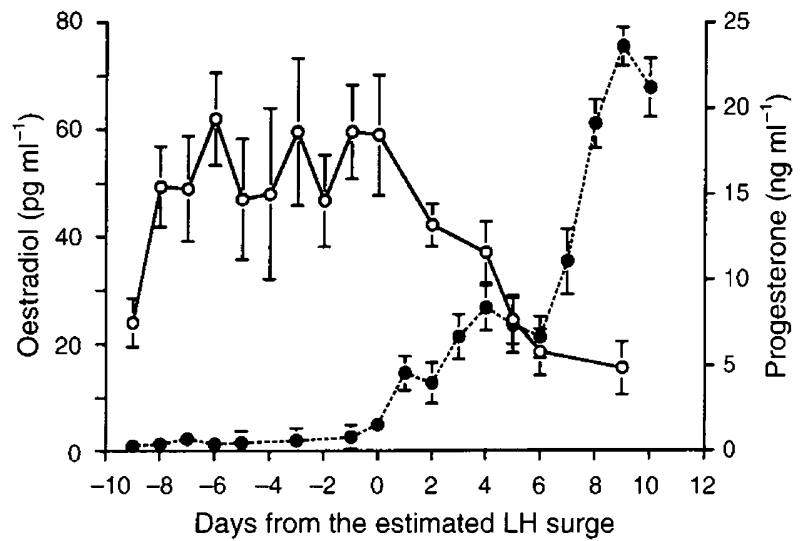

Fig. 4. Mean $( \pm$ SEM) concentrations of oestradiol $(O)$ and progesterone (O) in plasma around the time of the spontaneous ovulatory LH surge in seven beagle bitches in which oestrus and ovulation were induced by administration of 0.1 iu pig $\mathrm{LH} \mathrm{kg}^{-1}$ every $8 \mathrm{~h}$ for 7 days.

three response groups, the peak oestradiol concentrations in individual animals during the period of treatment were $68 \pm 4$, $27 \pm 2$ and $23 \pm 12 \mathrm{pg} \mathrm{ml}^{-1}$, respectively. In most bitches, there was a small decline in oestradiol before the end of LH treatment and a further decline in oestradiol on day 7 after the start of treatment, $10 \mathrm{~h}$ after the last injection of LH on day 6 (Fig. 2). Mean oestradiol on day 8 (about $32 \mathrm{~h}$ after the last injection) was lower $(P<0.05)$ than on day 6 while $\mathrm{LH}$ was still being administered ( $10 \pm 3$ versus $25 \pm 5 \mathrm{pg} \mathrm{ml}^{-1}$ ).

Changes in oestradiol and progesterone in the seven bitches that responded with a fertile pro-oestrus and oestrus, when considered relative to the first increase in progesterone (day 0 ) of the induced cycle, included preovulatory declines in oestradiol and increases in progesterone similar in magnitude to those of naturally occurring cycles (Fig. 4). Peak individual preovulatory oestradiol ranged from 55 to $97 \mathrm{pg} \mathrm{m}^{-1}$ (mean, $76+5 \mathrm{pg} \mathrm{ml}^{-1}$ ) and occurred $0-3$ days before the first increase in progesterone above $1.0 \mathrm{ng} \mathrm{ml}^{-1}$ (day 0 ). In five of the seven bitches the preovulatory oestradiol peak represented a distinct second peak in oestradiol 3-12 days after the decline in oestradiol that occurred after the last LH injection.

\section{Discussion}

The present results suggest that increased $\mathrm{LH}$ alone can initiate a competent follicular phase in bitches. Furthermore, functional pro-oestrus-like follicle development apparently does not require increases in FSH beyond the increased values already present throughout most of anoestrus. However, the purified LH preparation used in this study was of pig origin and, in theory, could have FSH-like activity in some species and not others. Equine chorionic gonadotrophin, which is mostly LH-like in its activity in horses, is considered to have primarily FSH-like activity in rodents and ruminants (Murphy and Martinuk, 1991). However, the same pig LH preparation has LH-like activity in cattle (Nowshari et al., 1995).

Since the dog is a mono-oestrous species characterized by a prolonged obligate anoestrus between successive cycles, it is not unexpected that the mechanisms for initiation of the follicular phase in bitches appear to be different from those of polyoestrous species. The results of the present study, together with previous reports of increased $\mathrm{FSH}$ concentrations during anoestrus (Olson et al., 1982; Concannon, 1993), suggest that pro-oestrus-like ovarian activity in bitches may be primarily dependent on availability of adequate $\mathrm{LH}$, and that FSH is routinely present in sufficient amounts. Endogenous factors regulating the availability or efficacy of LH in the normal bitch cycle probably include progesterone and prolactin. Exogenous progesterone prevents initiation of follicular phases in bitches (Concannon et al., 1993), and premature induction of luteolysis by prostaglandin treatment appears to shorten anoestrus (Romagnoli et al., 1993). In the present study, progesterone was $<\left.\mathrm{Ing} \mathrm{ml}\right|^{-1}$ at the start of treatment in all bitches. Whether administration of $\mathrm{LH}$ with progesterone $>1 \mathrm{ng} \mathrm{ml}^{-1}$ could induce pro-oestrus was not determined. The time at which progesterone declined below $1 \mathrm{ng} \mathrm{ml}{ }^{-1}$ was not determined, and the possible effect of duration of hypo-progesteronaemia before treatment was not evaluated.

Administration of a dopamine agonist can terminate anoestrus in bitches and cause a premature follicular phase, an effect possibly due to suppression of prolactin secretion (Concannon, 1993; Onclin et al., 1995). In the present study, LH administration was able to rapidly overcome the effects of any endogenous dopaminergic-dependent factors that normally promote the state of obligate anoestrus in bitches.

The mechanism of action of LH in causing increased follicular activity may be multiple, but the rapid increase in oestradiol in bitches treated with LH suggests that increased follicle steroidogenesis is a primary effect of $\mathrm{LH}$. An increase in follicular progesterone and androgen production stimulated by $\mathrm{LH}$ would be expected to result in an immediate increase in peripheral oestradiol if there were sufficient pre-existing aromatase activity. In the present study, oestradiol was increased within 1 day of treatment, at the earliest time studied (20-24 h). The potential for the anoestrous canine ovary to increase oestradiol production rapidly has been demonstrated by increases in oestradiol at $90 \mathrm{~min}$ after GnRH injection (Jeffcoate, 1993). Follicular aromatase in rats and most other species studied appears to be primarily under upregulation control by FSH (Gore-Langton and Armstrong, 1994) and, therefore, should not be limiting in bitches in which FSH is moderately and persistently high during anoestrus. Even if aromatase activity was limited to constitutive expression in anoestrous bitch follicles owing to a hypothetical deficiency of FSH receptors, the initial steroidogenic effect of LH might be expected to result in a sufficient increase in oestradiol to initiate a paracrine or autocrine effect on follicle growth and further oestradiol secretion. Intrafollicular oestradiol itself is folliculotrophic and stimulates aromatase activity (Gore-Langton and Armstrong, 1994). The large decline in oestradiol after the cessation of LH treatment further suggests that the increase in oestrogen was as a result of $\mathrm{LH}$ administration. The obvious declines in oestradiol shortly before the end of treatment suggest that the response to LH stimulation may decrease after several days. The involvement of a potential rapid immune response to administration of heterologous LH was not evaluated, but seems unlikely in the absence of an adjuvant. The decreased response to LH may be physiological. In spontaneous cycles, oestradiol often declines in late 
pro-oestrus, I-2 days before the ovulatory $\mathrm{LH}$ surge (Concannon et al., 1975; Nett et al., 1975).

Changes in oestradiol and progesterone in the seven bitches that responded with a fertile pro-oestrus and oestrus, when considered relative to day 0 of the induced cycle, were similar to those previously reported for normal ovarian cycles in bitches (Concannon et al., 1975). Therefore, in bitches, administration of $\mathrm{LH}$ alone resulted in follicular phases similar to those that occur spontaneously at the end of normal obligate anoestrus. Whether frequent administration of commercially available LH-like gonadotrophins, like hCG, could also be used to induce fertile ovarian cycles in canine anoestrus has not been studied, but may be of practical use in the clinical or experimental management of ovarian cycles in dogs.

The authors acknowledge the gift of purified pig LH kindly provided by J. F. Beckers, University of Liege, and the technical assistance of M. Warnier, P. Wauters-Ballman, and L. Newton. The food supply was provided by Hill's Animal Nutrition (Brussels).

\section{References}

Beckers JF, Closset J, MaguirRogister G and Hennen G (1977) Bovine follitropin: isolation and characterization of the native hormone and its alpha and beta subunits Biochemie $59825-831$

Cain JL, Lasley BL, Cain GR, Feldman EC and Stabenfeldt GH (1989) Induction of ovulation in bitches with pulsatile or continuous infusion of $\mathrm{GnRH}$ Journal of Reproduction and Fertility Supplement 39 143-147

Cain JL, Davidson AP, Cain GR, Stabenfeldt GH, Feldman EC and Lasley BL (1990) Induction of ovulation in bitches using subcutaneous injection of $\mathrm{GnRH}$ analog Journal of Veterinary Internal Medicine 4 (2) Abstract 124

Catt KJ, Dufau M and Tsuruhara T (1972) Radioligand-receptor assay of luteinizing hormone and chorionic gonadotrophin Journal of Clinical Endocrinology and Metabolism 34 123-132

Closset J, Vandalem JL, Hennen G and Lequin R (1975) Human luteinizing hormone: isolation and characterization of the native hormone and its alpha and beta subunits European Journal of Biochemistry 57 325-353

Concannon PW (1993) Biology of gonadotrophin secretion in adult and prepubertal female dogs Journal of Reproduction and Fertility Supplement 47 3-27

Concannon PW and DiGregorio GB (1986) Canine vaginal cytology. In Small Animal Reproduction and Infertility pp 96-111 Ed. T Burke. Lea and Febiger, Philadelphia

Concannon PW, Hansel W and Visek W (1975) The ovarian cycle of the bitch: plasma estrogen, LH and progesterone Biology of Reproduction 13 112-I21

Concannon PW, Hansel W and McEntee $\mathrm{K}$ (1977) Changes in LH, progesterone and sexual behavior associated with preovulatory luteinization in the bitch Biology of Reproduction 17 604-613

Concannon PW, Weinstein R, Whaley S and Frank D (1987) Suppression of luteal function in dogs by luteinizing hormone anti-serum and by bromocriptine Journal of Reproduction and Fertility 81 175-180
Concannon PW, Temple M, Montanez A and Frank D (1993) Synchronous delayed oestrus in beagle bitches given infusions of $\mathrm{GnRH}$ superagonist following withdrawal of progesterone implants Journal of Reproduction and Fertility Supplement $47522-523$

Concannon P, Lasley B and Vanderlip S (1997) LH release, induction of oestrus and fertile ovulations in response to pulsatile administration of $\mathrm{GnRH}$ in anoestrous dogs Journal of Reproduction and Fertility Supplement $\mathbf{5 1}$ 41-54

Ectors F, Hendrick JC, Franchimont P and Derivaux J (1974) Recherches radio-immunologiques sur la teneur plasmatique en $\mathrm{LH}$ chez les bovins Annales d'Endocrinologie 35 489-497

Gorelangton RE and Armstrong DT (1994) Follicular steroidogenesis and its control. In The Physiology of Reproduction pp 571-628 Eds E Knobil and ID Neill. Raven Press, New York

Haaften BV, Bevers MM, Brom WEvd, Dieleman SJ, Okkens AC, Sluijs FJ and Willemse AH (1992) Increasing sensitivity of the pituitary for GnRH from early to advanced anoestrus in the beagle bitch Proceeding of the 12th International Congress Animal Reproduction (The Hague) 4 1829-1831

Jeffcoate IA (1993) Endocrinology of anoestrous bitches Journal of Reproduction and Fertility Supplement 47 69-76

Murphy BD and Martinuk SD (1991) Equine chorionic gonadotropin Endocrine Reviews 12 27-44

Nett TM, Akbar AM, Phemister RD, Holst PA, Reichert LE, Jr and Niswender GD (1975) Levels of luteinizing hormone, estradiol and progesterone in serum during the estrous cycle and pregnancy in the beagle bitch Proceedings of the Society for Experimental Biology and Medicine 148 134-139

Nowshari MA, Beckers JF and Holtz W (1995) Superovulation of goats with purified pFSH supplemented with defined amounts of pLH Theriogenology 43 797-802

Olson PN, Bowen RA, Behrendt M, Olson JD and Nett TM (1982) Concentrations of reproductive hormones in canine serum throughout late anestrus, proestrus and estrus Biology of Reproduction 27 1196-1206

Onclin K, Silva LDM, Donnay I and Verstegen J (1993) Luteotrophic action of prolactin in dogs and the effects of a dopamine agonist, cabergoline Journal of Reproduction and Fertility Supplement 47 403-409

Onclin K, Verstegen J, Silva LDM and Concannon P (1995) Patterns of circulating prolactin, $\mathrm{LH}$ and FSH during dopamine agonist induced termination of anestrus in beagle dogs Biology of Reproduction $\mathbf{5 2}$ (Supplement 1) Abstract 135

Romagnoli SE, Camillo F, Cela M, Johnston SD, Grassi F, Ferdeghini M and Aria G (1993) Clinical use of prostaglandin $\mathrm{F}_{2 a}$ to induce early abortion in the bitch: serum progesterone, treatment outcome and interval to subsequent oestrus Journal of Reproduction and Fertility Supplement 47 433-438

Snedecor GW and Cochran WG (1980) Statistical Methods 7th edn. lowa State University Press, Ames, IA

Srikandakumar A, Ingraham RH, Ellsworth M, Archbald LF, Liao A and Godke RA (1986) Comparison of a solid-phase, no-extraction radioimmunoassay for progesterone with an extraction assay for monitoring luteal function in the mare, bitch, and cow Theriogenology 26 779-793

Vanderlip S, Wing A, Linke D, Rivier J, Concannon PW and Lasley B (1987) Ovulation induction in anestrous bitches by pulsatile administration of gonadotropin releasing hormone $(\mathrm{GnRH})$ Laboratory Animal Science 37(4) 459-464 